\title{
Application of X-ray tomography to quantify macropore characteristics of loess soil under two perennial plants
}

\author{
T. C. L I ${ }^{\mathrm{a}}, \mathrm{M} \cdot \mathrm{A} \cdot \mathrm{S} \mathrm{H} \mathrm{A} \mathrm{O}^{\mathrm{a}, \mathrm{b}} \& \mathrm{Y} \cdot \mathrm{H} \cdot \mathrm{J}_{\mathrm{I}} \mathrm{a}^{\mathrm{b}, \mathrm{c}}$ \\ ${ }^{\mathrm{a}}$ College of Resources and Environment, Northwest A\&F University, Yangling 712100, China, ${ }^{\mathrm{b}}$ Key Laboratory of Ecosystem Network \\ Observation and Modeling, Institute of Geographic Sciences and Natural Resources Research, Chinese Academy of Sciences, Beijing \\ 100101, China, and ${ }^{\mathrm{C} C o l l e g e}$ of Water Conservancy, Shenyang Agricultural University, Shenyang, 110866, China
}

\begin{abstract}
Summary
With the advent of large-scale restoration of vegetation in the Loess Plateau, northwest China, there has been an increase in concern about the suitability of loess soil to support permanent vegetation cover. The quantification of soil macropore characteristics could be critical in determining the architecture and hydrological processes of loess soil on the plateau. In this research, we compared the effects of Purple alfalfa (Medicago sativa L.) and Korshinsk peashrub (Caragana korshinskii K.) on the macropore characteristics of a soil profile on the plateau with computed tomography (CT). To achieve this, undisturbed cores of soil were excavated from beneath purple alfalfa (ALF), 22-year-old Korshinsk peashrub $\left(\mathrm{KOP}_{22}\right)$ and 40-year-old Korshinsk peashrub $\left(\mathrm{KOP}_{40}\right)$ vegetation types in the Liudaogou watershed for evaluation. The soil macropore characteristics (including macroporosity, largest pore area, amounts of macropores, circularity, surface area density, branch density, junction density and connectivity) were determined with image analysis software. Soil under $\mathrm{KOP}_{22}$ and $\mathrm{KOP}_{40}$ treatments had approximately the same amounts of macropores (17 per 6359- $\mathrm{mm}^{2}$ area), which was three times greater than those under ALF plants. Macroporosity ratios of soil under $\mathrm{KOP}_{22}$ and $\mathrm{KOP}_{40}$ plants to that under ALF plants were 2.3 and 3.6, respectively. Compared with $\mathrm{KOP}_{22}, \mathrm{KOP}_{40}$ had a larger macroporosity and the largest pore area at the 100-300-mm soil depth. The KOP plants, in particular $\mathrm{KOP}_{40}$, apparently improved the macropore network structure of the soil more than ALF. However, the macropores under ALF were much rounder at the 100-300-mm soil depth than those under the other two plants. There was no correlation between macropore characteristics and organic matter content of the soil at 100-400-mm depth. Nevertheless, macroporosity was strongly correlated with the largest pore area. The findings of this research are critical for developing strategies for the restoration of vegetation in the Loess Plateau through improvement of the hydrological process of loess soil.
\end{abstract}

\section{Highlights}

- We examined macropore characteristics of loess soil on the Loess Plateau in China.

- We determined the effects of different plants on soil macropore characteristics.

- Soil under Korshinsk peashrub had better macropore structure than that under Purple alfalfa.

- Long-term recovery of KOP benefits the macropore structure most on the northern Loess Plateau.

\section{Introduction}

Severe and widespread soil erosion has brought the restoration of vegetation to the forefront of soil conservation efforts on the Loess Plateau, northwest China. Some $24 \%$ of the eroded regions of the Loess Plateau have been controlled since the 1980s (He etal., 2003). The restoration of vegetation on the plateau has

Correspondence: M. A. Shao. E-mail: shaoma@igsnrr.ac.cn

Received 10 March 2015; revised version accepted 13 January 2016 benefited most from the Grain for Green Project that started in 1999. In the Loess Plateau, the objective of this project was to increase vegetation cover on the plateau by planting trees and sowing grasses on barren croplands. The Grain for Green Project involved considerable investment from the Chinese Government and by the end of 2005 it had covered some $87000 \mathrm{~km}^{2}$ of land on the plateau with the planting of about 400-600 million trees (Zhou et al., 2009).

The substantial increase in vegetation cover (Zhou et al., 2012) had a marked effect on properties of the soil, including deep 
soil profile water content (Cao etal., 2009; Wang etal., 2010; Jia \& Shao, 2014). This has, however, hindered the sustainable development of vegetation in the plateau region. One reason is the development of dry layers in the soil, which is considered to be a new obstacle to vegetation growth and succession in the region (Chen etal., 2008; Wang etal., 2010). Because of this, efforts to increase the infiltration and storage of rainwater in the soil have become more urgent.

Zhao etal. (2010) noted that natural vegetation recovery could improve considerably soil pore characteristics that are closely related to water storage and the regulating capacity of the soil water reservoir. Characterization of soil pores in the arid Loess Plateau region could, therefore, be useful for developing strategies to avoid water shortage at depth in the soil profile and for vegetation recovery in the region. The uniqueness of eroded landforms on the plateau makes characterization of the soil pores especially necessary. So far, research on this feature of the Loess Plateau is largely insufficient.

Conventional methods of soil pore research are indirect and lack sufficient detail. Computed tomography (CT) procedures, however, are more exact, use non-destructive strategies for observation and have fine resolutions (Cnudde \& Boone, 2013). Soil pore characteristics, such as pore shape, size, orientation and size distribution, can be determined accurately with the X-ray CT device (Rab et al., 2014). Furthermore, there are promising applications of the CT method in other fields of soil science, such as the measurement of bulk density, solute transport, soil hydraulic properties, soil quality, plant root development and three-dimensional reconstruction (Jarvis, 2007; Elliot et al., 2010; Alaoui et al., 2011; Li et al., 2014). In view of the versatility of CT, its application in soil physics, for example to quantify soil macropores, is increasing in popularity.

There is abundant research on the effect of vegetation recovery on soil physical properties in the Loess Plateau. The studies have shown that soil porosity has increased from $51.4 \%$ on agricultural land to $62.7 \%$ in forests under long-term natural vegetation in Ziwuling (Li \& Shao, 2006). Jiao et al. (2011) observed that land use affects markedly soil bulk density, total porosity and capillary porosity of the surface soil layer. Bulk density varies with the slope position of Caragana korshinskii K. (Korshinsk peashrub, KOP) shrubs in gullies on the Loess Plateau (Xu et al., 2014). Furthermore, $\mathrm{Hu}$ et al. (2009) noted a considerable change with time in the effect of soil pores on the hydrology of alfalfa and Korshinsk peashrub fields in the Liudaogou Catchment. Although this discovery has deepened our insight into soil pore structures in the Loess Plateau, soil macropore characteristics of loess soil have not been explained clearly because of limitations in traditional methods of studying them. The CT technique is used in soil science and its value as an advanced and efficient method has been proved, but it has not yet been used to study loess soil in the Loess Plateau of China. Furthermore, there has not been enough research on the characteristics of surface soil pores in relation to the period of vegetation restoration (Udawatta et al., 2006; Zhao et al., 2010; Yang et al., 2013).

In this research, $360 \mathrm{CT}$ images were used to evaluate soil pore structures at $0-400-\mathrm{mm}$ depth in the soil of the Liudaogou Catchment. The objectives of this study were to (i) evaluate differences in the number of CT-measured macropores, macroporosity, largest pore area, circularity, surface area density, branch density, junction density and connectivity of loess soil under ALF (Medicago sativa L.), $\mathrm{KOP}_{22}$ (22-year-old Korshinsk peashrub) and $\mathrm{KOP}_{40}$ (40-year-old Korshinsk peashrub) vegetation types and (ii) correlate the CT-measured pore properties with soil organic matter content and root characteristics. The results of the research will provide further insight into the interactions among macropore characteristics, the plant root system and soil properties in the northern Loess Plateau.

\section{Materials and methods}

\section{Experimental site and soil sample preparation}

Liudaogou Catchment is on the northern Loess Plateau and is about $14 \mathrm{~km}$ west of Shenmu County, Shaanxi Province, China. The location of the catchment is $110^{\circ} 21^{\prime}-110^{\circ} 23^{\prime} \mathrm{E}$ and $38^{\circ} 46^{\prime}-38^{\circ} 51^{\prime} \mathrm{N}$, and it is at an elevation range of $1094-1274 \mathrm{~m}$ (Figure 1). The catchment is in a moderate temperate, semi-arid zone with a mean annual precipitation of $430 \mathrm{~mm}$, some $77 \%$ of which occurs between July and September. The average annual temperature is $8.4^{\circ} \mathrm{C}$, with a

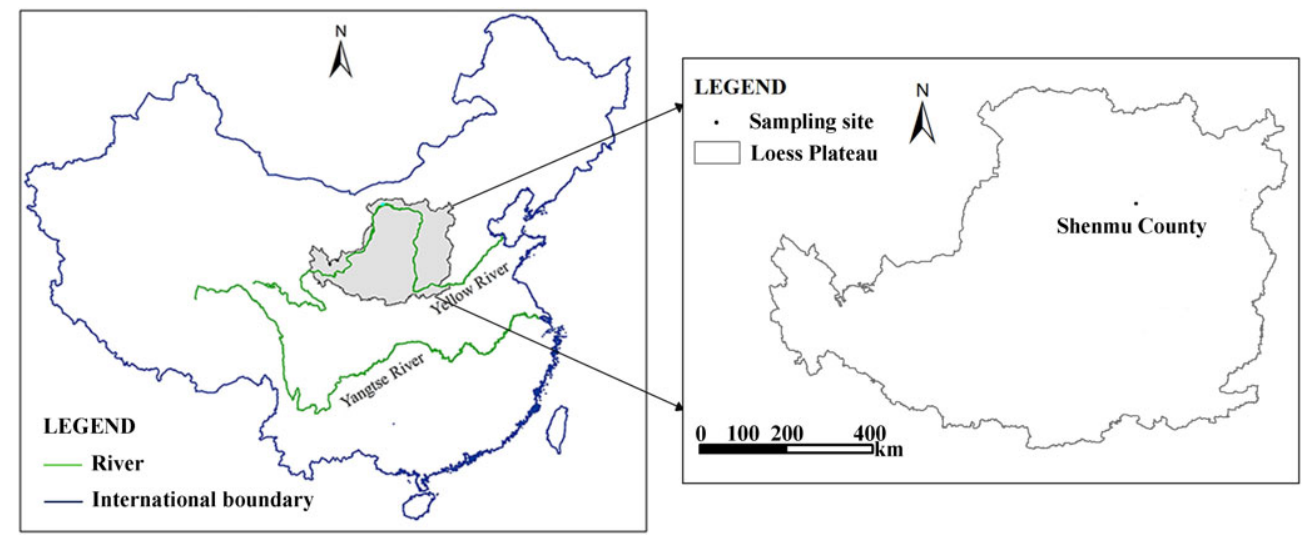

Figure 1 Map of the location of the study area in China and of the sampling sites in the Loess Plateau. 
mean annual potential evapotranspiration of $785 \mathrm{~mm}$. The catchment is representative of the transition belt because it is subjected to both wind and water erosion. The soil is a Calcaric Regosol (FAO, 1989; Wei etal., 2013) of loess origin with weak cohesion, large infiltration rate, small water retention and poor fertility.

A survey of Liudaogou Catchment showed that restored grass and forest form only small patches of vegetation in the study area. The most important and widely planted species of perennial plants in the region are purple alfalfa (Medicago sativa L.) and Korshinsk peashrub (Caragana korshinskii K.). They are commonly planted on degraded slopes with no fertilizer application or irrigation, and purple alfalfa is cut once or twice a year for livestock feed. In addition, there is sporadic needlegrass (Stipa bungeana T.) in areas not covered by these two perennial plants above.

Cores of soil were taken under the two vegetation types, including both 22-year-old and 40-year-old KOP. Therefore, in effect three vegetation treatments $\left(\mathrm{ALF}, \mathrm{KOP}_{22}\right.$ and $\mathrm{KOP}_{40}$ ) were covered in the study. Soil texture, slope aspect and elevation were quite consistent at the three sampling sites.

To preserve the natural continuity of macropores and to improve our understanding, undisturbed cores from 0- to 400-mm depth in the profile were taken at each site on 4 and 5 June 2014, whereas previous studies apparently used short soil cores of less than $100 \mathrm{~mm}$. A polyvinyl chloride (PVC) cylinder, 400-mm long, 110 -mm wide and with a 3-mm-thick wall, was used to collect the soil core samples. To do this, a representative plant was selected from each plant cover type. Because of the cost of labour for deeper sampling and processing of the scanned images, two cores only were collected for each treatment.

Soil macropore characteristics can differ greatly with distance from a perennial plant because of root development. To deal with this variation, two replicate samples were taken $50 \mathrm{~cm}$ from the plant in each treatment. Before the core was taken, the litter was removed completely and bare soil exposed. The PVC cylinders (with a sharp edge) were hammered vertically and fully into the ground with a plastic hammer and a rubber dumbell, then they were dug out with a shovel. Two PVC caps and masking tape were used to secure the soil inside the cylinders and protect it during transport. The soil cylinders were labelled, placed in plastic bags and sealed until they were scanned by CT. Throughout this process, care was taken to avoid disturbing the samples. Next, disturbed soil samples were taken from depths of 0 to 100,100 to 200,200 to 300 and 300 to $400 \mathrm{~mm}$. Soil organic matter and particle-size distribution in these samples were measured in the laboratory (Table 1).

Root features can effectively explain soil pore characteristics; therefore, we used Korshinsk peashrub root data for this. The root sampling sites were the same as the soil core sampling sites; all root analyses were completed in June 2011. The sampling areas of KOP treatments were determined by the canopy areas, which were $3 \mathrm{~m} \times 3 \mathrm{~m}$ and $2.7 \mathrm{~m} \times 2.5 \mathrm{~m}$ with a total volume of each $10-\mathrm{cm}$ layer of 900000 and $675000 \mathrm{~cm}^{3}$ for the $\mathrm{KOP}_{22}$ and $\mathrm{KOP}_{40}$ treatments, respectively. The KOP roots were obtained by manual excavation and were washed before measurement. The average diameter and length of thick roots were measured with a vernier
Table 1 Mean soil organic matter content and particle-size fractions of sand, silt and clay in the purple alfalfa (ALF), 22-year-old Korshinsk peashrub $\left(\mathrm{KOP}_{22}\right)$ and 40-year-old Korshinsk peashrub $\left(\mathrm{KOP}_{40}\right)$ treatments at the $0-100,100-200,200-300$ and 300-400-mm depths in the northern Loess Plateau of China

\begin{tabular}{|c|c|c|c|c|}
\hline \multirow[b]{2}{*}{ Property } & \multirow{2}{*}{$\begin{array}{l}\text { Organic matter / } \\
\mathrm{g} \mathrm{kg}^{-1}\end{array}$} & \multicolumn{3}{|c|}{ Particle-size distribution / \% } \\
\hline & & Sand & Silt & Clay \\
\hline ALF & 6.9 & 39.6 & 51.0 & 9.4 \\
\hline $\mathrm{KOP}_{22}$ & 3.7 & 32.3 & 58.5 & 9.2 \\
\hline $\mathrm{KOP}_{40}$ & 4.6 & 42.2 & 47.2 & 10.7 \\
\hline $0-100 \mathrm{~mm}$ & 10.1 & 45.3 & 46.1 & 8.6 \\
\hline $100-200 \mathrm{~mm}$ & 4.9 & 38.7 & 52.2 & 9.1 \\
\hline $200-300 \mathrm{~mm}$ & 2.7 & 35.6 & 54.2 & 10.2 \\
\hline $300-400 \mathrm{~mm}$ & 2.6 & 32.5 & 56.4 & 11.1 \\
\hline
\end{tabular}

calliper. Fine root data were obtained by scanning and image analysis. An ordinary scanner (CanoScan LiDE 100, Beijng, China) was used with the resolution set at $300 \times 300 \mathrm{DPI}$. The fine root binary images obtained were analysed by Delta-T scan software, developed in 1993 by Delta-T Devices Ltd, Cambridge, UK. The absence of data on ALF roots was mainly because they have a deep taproot system and shallow roots were not considered to provide sufficient information. The root data (sample area, average diameter and length density) for $\mathrm{KOP}_{22}$ and $\mathrm{KOP}_{40}$ treatments only were used in this study.

\section{Scanning and image analysis}

A Philips MX16 CT scanner (Amsterdam, the Netherlands) at Yangling Hospital was used to acquire CT images. The scan system was set to $140 \mathrm{kV}, 200 \mathrm{mAs}$ and $21.4 \mathrm{~s}$ scan time for detailed and low-noise projection of $1 \mathrm{~mm} \times 1 \mathrm{~mm}$. The X-ray beam width or 'slice' thickness was $1 \mathrm{~mm}$, which produced a volume element (voxel) size of $1 \mathrm{~mm}^{3}$. The scanner resolution limits the size of the smallest pore that can be detected with this procedure. Six soil cores were positioned horizontally on the scanning stage to have a perpendicular X-ray beam along the longitudinal axis. Because the soil at the top and bottom of the cores was more or less disturbed during field acquisition, transport and placement, the top and bottom $20 \mathrm{~mm}$ were disregarded to restrict the depth range of scanning to $360 \mathrm{~mm}$. The data were then stored for subsequent image analysis.

The pore characteristics of the scanned images were analysed with the ImageJ software (version 1.48) (Rasband, 2002), which is in the public domain. A circular area of $6359 \mathrm{~mm}^{2}$ (with a $90-\mathrm{mm}$ diameter) was demarcated by the area selection tools as the 'region of interest (ROI)' and then the exterior area was deleted to exclude voids near core walls and to minimize beam-hardening interference. The segmentation procedure separated the two populations within an image based on intensity values. With a 'threshold tool', the intensity of water phantoms $($ mean $=40)$ was considered the standard threshold to distinguish air-filled pore areas and the other regions within the 8-bit greyscale (range 1-255) image. Values less 
(a)

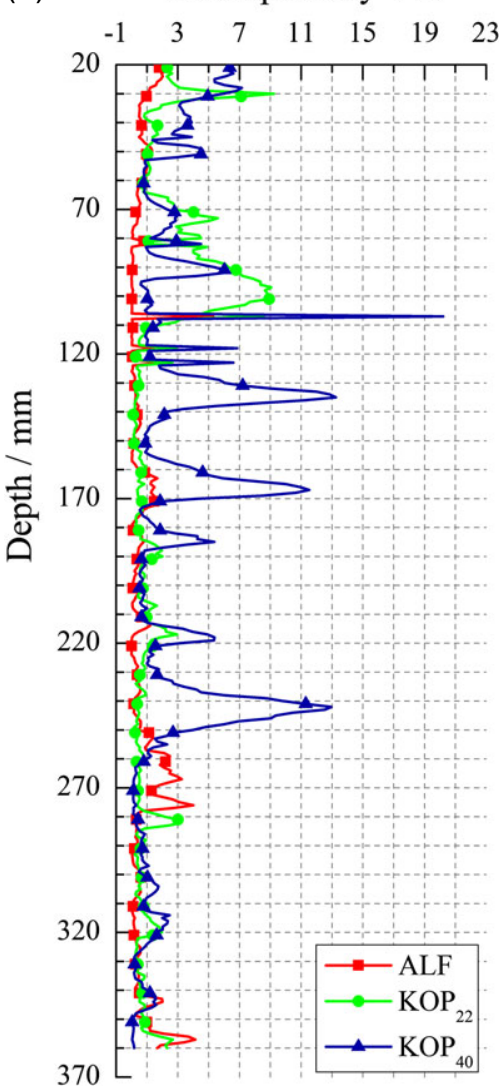

(b) Area of largest pore $/ \mathrm{mm}^{2}$

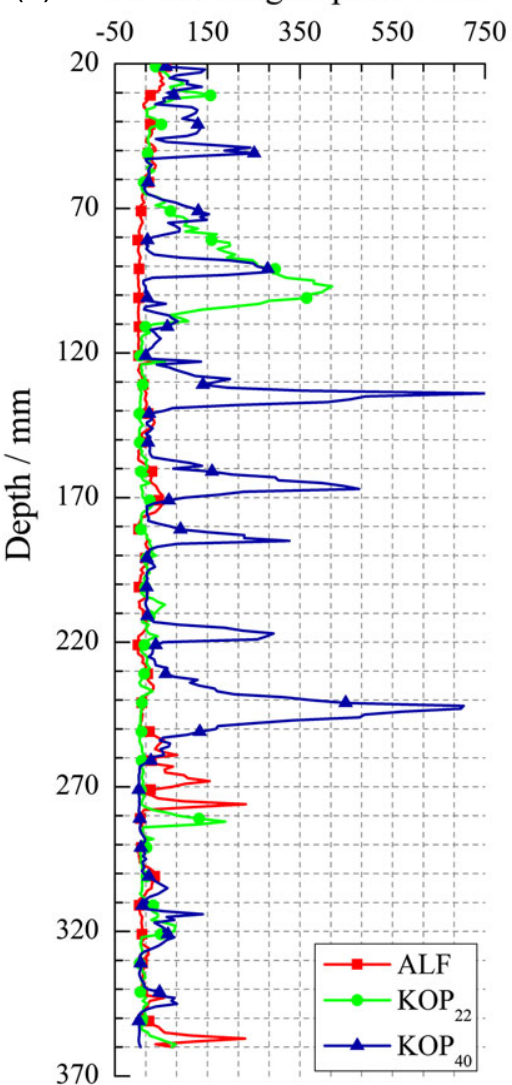

(c) Number of Macropores

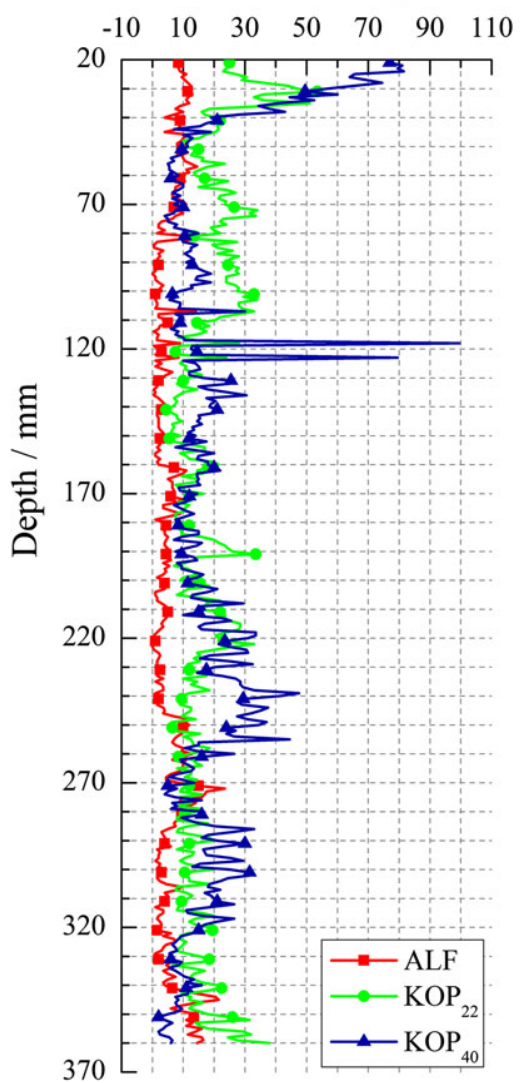

Figure 2 (a) Macroporosity, (b) largest macropore area and (c) macropore number at every 1-mm interval of the 20-360-mm depth under ALF (purple alfalfa), $\mathrm{KOP}_{22}$ (22-year-old Korshinsk peashrub) and $\mathrm{KOP}_{40}$ (40-year-old Korshinsk peashrub) vegetation in the Loess Plateau.

than the threshold value were identified as air-filled pores and those that were larger were identified as non-pores. Because of limitations of the CT resolution, the pores from the ImageJ analysis were all classified as macropores (Scott, 2000). Details of the image analysis can be found in Udawatta et al. (2006) and Doube et al. (2010).

\section{Statistical analysis}

The average value of the two samples taken for each depth was used to determine the correlation between macropore characteristics and soil depth (Figure 2). To analyse the correlation between macropore characteristics and soil properties, the $360-\mathrm{mm}$ soil depth was divided into four zones (0-100, 100-200, 200-300 and $300-400 \mathrm{~mm}$ ) as in Tables $1-4$. The means of the treatment in Tables 1 and 2 denote the average values of the 360-mm depth for each treatment. Note that the mean of the depth is the average of the three treatments. Descriptive statistics (including mean, minimum, maximum, standard deviation and coefficient of variation) for the different soil depths and treatments were used to evaluate the effects of depth and treatment on macropore characteristics (Tables 2 and 3). Correlation analysis was used to determine the relations between macropore properties, particle-size distribution and organic matter content.

\section{Results}

\section{Macroporosity and largest pore area}

The results of the quantitative analysis of the macropores of loess soil in this study are given in Tables 2 and 3. The mean macroporosities of the ALF, $\mathrm{KOP}_{22}$ and $\mathrm{KOP}_{40}$ treatments are 0.65 , 1.51 and $2.31 \%$, respectively. The range of macroporosity of $\mathrm{KOP}_{40}$ is wider than that of the other two treatments. The mean values of the largest pore areas under $\mathrm{KOP}_{22}$ and $\mathrm{KOP}_{40}$ are 2.1 and 3.6 times larger than those under ALF. The coefficients of variation $(\mathrm{CVs})$ of macroporosity and largest pore area of the three treatments are all $>1$ (Table 2). This suggests considerable variation in these two properties along the $360-\mathrm{mm}$ depth beneath the vegetation types.

Table 3 also indicates that the mean values of macroporosity and largest pore area under $\mathrm{KOP}_{40}$ are larger than those under ALF, especially for the first $(0-100 \mathrm{~mm})$, second $(100-200 \mathrm{~mm})$ and third (200-300 mm) soil depths. The means of macroporosity and largest pore area under $\mathrm{KOP}_{22}$, however, are close to those for ALF for depths 200-300 and 300-400 mm (Table 3). The soil under $\mathrm{KOP}_{40}$ has larger mean values of macroporosity and largest pore area for depths 100-200 and 200-300 mm than for soil under $\mathrm{KOP}_{22}$. For the 200-300-mm depth, the values of macroporosity and largest pore area under $\mathrm{KOP}_{22}$ are 36 and $21 \%$ of those under 
Table 2 Summary statistics of soil macroporosity under purple alfalfa (ALF), 22-year-old Korshinsk peashrub (KOP 22 ) and 40-year-old Korshinsk peashrub $\left(\mathrm{KOP}_{40}\right)$ plants for the $0-100,100-200,200-300$ and 300-400-mm depths in the northern Loess Plateau of China

\begin{tabular}{|c|c|c|c|c|c|c|c|c|c|c|c|c|c|c|c|c|c|c|c|c|}
\hline \multirow[b]{2}{*}{ Property } & \multicolumn{5}{|c|}{ Macroporosity / \% } & \multicolumn{5}{|c|}{ Largest pore area $/ \mathrm{mm}^{2}$} & \multicolumn{5}{|c|}{ Macropore count / N } & \multicolumn{5}{|c|}{ Macropore circularity } \\
\hline & Mean & Max. & Min. & SD & $\mathrm{CV}$ & Mean & Max. & Min. & SD & $\mathrm{CV}$ & Mean & Max. & Min. & SD & $\mathrm{CV}$ & Mean & Max. & Min. & SD & $\mathrm{CV}$ \\
\hline $\mathrm{KOP}_{22}$ & 1.51 & 9.22 & 0.11 & 1.88 & 1.25 & 44.9 & 419.0 & 2.0 & 75.1 & 1.67 & 17 & 54 & 5 & 8 & 0.48 & 0.92 & 1.00 & 0.77 & 0.04 & 0.05 \\
\hline $\mathrm{KOP}_{40}$ & 2.31 & 20.22 & 0.05 & 2.83 & 1.23 & 77.9 & 750.5 & 1.0 & 116.9 & 1.50 & 18 & 100 & 2 & 14 & 0.80 & 0.92 & 1.00 & 0.71 & 0.05 & 0.05 \\
\hline $0-100 \mathrm{~mm}$ & 2.27 & 3.28 & 0.62 & 1.44 & 0.63 & 72.2 & 110.0 & 18.3 & 47.9 & 0.66 & 18 & 24 & 7 & 9 & 0.50 & 0.91 & 0.93 & 0.89 & 0.02 & 0.02 \\
\hline $300-400 \mathrm{~mm}$ & 0.83 & 0.89 & 0.74 & 0.08 & 0.10 & 25.6 & 29.5 & 21.8 & 3.8 & 0.15 & 11 & 15 & 7 & 4 & 0.36 & 0.94 & 0.94 & 0.93 & 0.01 & 0.01 \\
\hline
\end{tabular}

Max., Min., SD and CV denote maximum, minimum, standard deviation and coefficient of variation, respectively.

Table 3 Summary statistics of macropore properties (macroporosity, largest pore area, macropore count and circularity) for the 0-100, 100-200, 200-300 and 300-400-mm soil depths under purple alfalfa (ALF), 22-year-old Korshinsk peashrub $\left(\mathrm{KOP}_{22}\right)$ and 40-year-old Korshinsk peashrub $\left(\mathrm{KOP}_{40}\right)$ treatments in the northern Loess Plateau of China

\begin{tabular}{|c|c|c|c|c|c|c|c|c|c|c|c|c|c|c|c|c|}
\hline Property & Depth / mm & Mean & Max. & Min. & SD & $\mathrm{CV}$ & Mean & Max. & Min. & SD & $\mathrm{CV}$ & Mean & Max. & Min. & SD & $\mathrm{CV}$ \\
\hline & $100-200$ & 0.46 & 5.30 & 0.01 & 0.68 & 1.47 & 1.12 & 8.93 & 0.11 & 1.76 & 1.57 & 3.26 & 20.22 & 0.51 & 3.67 & 1.13 \\
\hline & $200-300$ & 0.79 & 4.02 & 0 & 0.89 & 1.12 & 0.79 & 3.25 & 0.17 & 0.62 & 0.78 & 2.18 & 12.96 & 0.11 & 2.93 & 1.34 \\
\hline & $300-400$ & 0.74 & 4.14 & 0.06 & 0.86 & 1.16 & 0.85 & 2.68 & 0.24 & 0.59 & 0.69 & 0.89 & 2.47 & 0.05 & 0.70 & 0.78 \\
\hline & $100-200$ & 14.8 & 51.5 & 0.5 & 14.1 & 0.95 & 28.2 & 364.5 & 2.0 & 57.2 & 2.03 & 103.1 & 750.5 & 13.0 & 134.0 & 1.30 \\
\hline & $200-300$ & 27.0 & 233.0 & 0 & 35.5 & 1.31 & 19.4 & 188.5 & 2.0 & 27.5 & 1.42 & 90.5 & 704.4 & 1.5 & 148.8 & 1.64 \\
\hline & $300-400$ & 25.4 & 231.5 & 2.5 & 36.1 & 1.42 & 21.8 & 81.1 & 2.5 & 21.8 & 1.00 & 29.5 & 104.0 & 1.0 & 29.5 & 1.00 \\
\hline \multirow[t]{3}{*}{ Macropore count / N } & $0-100$ & 7 & 15 & 0 & 4 & 0.57 & 24 & 54 & 10 & 9 & 0.38 & 22 & 82 & 4 & 22 & 1.00 \\
\hline & $100-200$ & 4 & 14 & 1 & 3 & 0.75 & 14 & 34 & 5 & 7 & 0.50 & 15 & 100 & 6 & 12 & 0.80 \\
\hline & $200-300$ & 6 & 24 & 0 & 4 & 0.67 & 14 & 33 & 5 & 6 & 0.43 & 21 & 48 & 4 & 9 & 0.43 \\
\hline & $200-300$ & 0.94 & 1.00 & 0.76 & 0.05 & 0.05 & 0.93 & 1.00 & 0.77 & 0.04 & 0.04 & 0.94 & 1.00 & 0.82 & 0.04 & 0.04 \\
\hline & $300-400$ & 0.94 & 1.00 & 0.81 & 0.05 & 0.05 & 0.95 & 0.99 & 0.86 & 0.03 & 0.03 & 0.94 & 1.00 & 0.83 & 0.05 & 0.05 \\
\hline
\end{tabular}

Max., Min., SD and CV denote maximum, minimum, standard deviation and coefficients of variation, respectively.

$\mathrm{KOP}_{40}$, respectively. For the 300-400-mm depth, the difference in mean values between $\mathrm{KOP}_{22}$ and $\mathrm{KOP}_{40}$ is not marked (Table 3). Soil under ALF has larger means for macroporosity and largest pore area for the 300-400-mm than for the $0-100-\mathrm{mm}$ depths. In contrast, these values decrease by 77 and $68 \%$ from the first to the fourth soil depths, respectively, under the two KOP treatments (Table 3).

Figure 2(a,b) also shows similar trends of macroporosity and largest pore area to those in Table 3 , and provides more detail on the macropores. For soil under $\mathrm{KOP}_{40}$, the $\mathrm{CT}$ traces of macroporosity and largest pore area are irregular, with six maxima for the 90-240-mm soil depth. In contrast, the traces change little below a depth of $110 \mathrm{~mm}$ under $\mathrm{KOP}_{22}$. The values of macroporosity and largest pore area for soil under ALF are smaller than those for the KOP treatments, especially for the 20-120-mm depth (Figure 2a,b).
The average values for macroporosity $\left(0.64 \%\right.$, ALF; $0.78 \%, \mathrm{KOP}_{22}$; $\left.0.85 \%, \mathrm{KOP}_{40}\right)$ and largest pore area $\left(22.8 \mathrm{~mm}^{2}\right.$, ALF; $19.7 \mathrm{~mm}^{2}$, $\mathrm{KOP}_{22} ; 25.6 \mathrm{~mm}^{2}, \mathrm{KOP}_{40}$ ) below $285 \mathrm{~mm}$ are smaller than those above (Figure 2a,b). Furthermore, macroporosity was correlated with the largest pore area (not shown in the tables). The coefficients of determination between macroporosity and largest pore area are 0.807 (ALF), $0.847\left(\mathrm{KOP}_{22}\right)$ and $0.908\left(\mathrm{KOP}_{40}\right)$. The results suggest that the distribution of macroporosity is strongly affected by the largest pore area.

\section{Number of macropores}

The macropore count varied with treatment and soil depth. The $\mathrm{KOP}_{40}$ and $\mathrm{KOP}_{22}$ treatments have an average of 18 and 17 macropores, respectively, whereas ALF has only 6. The macropore 
Table 4 Root surface area density, average diameter and length density of 22-year-old Korshinsk peashrub $\left(\mathrm{KOP}_{22}\right)$ and 40 -year-old Korshinsk peashrub $\left(\mathrm{KOP}_{40}\right)$ for the 0-100, 100-200, 200-300 and 300-400-mm soil depths in the northern Loess Plateau of China

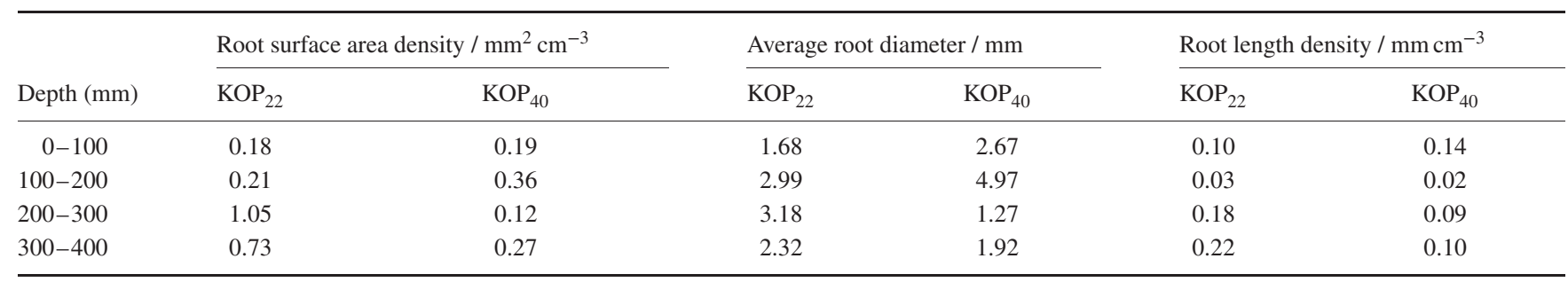

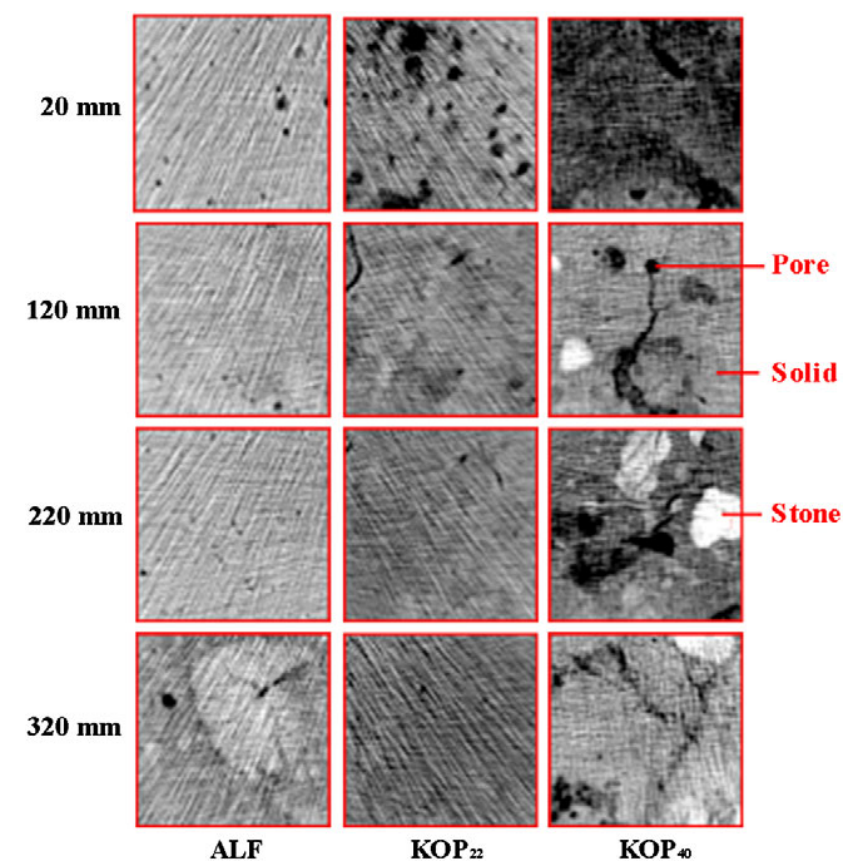

Figure 3 Typical cross-sections of scanned images of soil under ALF (purple alfalfa), $\mathrm{KOP}_{22}$ (22-year-old Korshinsk peashrub) and $\mathrm{KOP}_{40}$ (40-year-old Korshinsk peashrub) for cores at four selected soil depths $(20,120,220$ and $320 \mathrm{~mm})$ in the Loess Plateau. Macropores are shown in black, solid particles in grey and stones in white.

count along the 360 -mm depth under $\mathrm{KOP}_{40}$ varies between two and 100. This range is much greater than that under $\mathrm{KOP}_{22}$ and ALF (Table 2). Soil under $\mathrm{KOP}_{22}$ has 3.4, 3.5, 2.3 and 2.1 and $\mathrm{KOP}_{40}$ 3.1, 3.8, 3.5 and 1.7 more macropores than ALF at depths 0-100, 100-200, 200-300 and 300-400-mm, respectively (Table 3). The average macropore counts under ALF, $\mathrm{KOP}_{22}$ and $\mathrm{KOP}_{40}$ treatments at depth $0-100 \mathrm{~mm}$ are 60,30 and $60 \%$, respectively, larger than those at the other three depths (Table 2). For soil under $\mathrm{KOP}_{22}$ and $\mathrm{KOP}_{40}$, the macropore count at the 300-400-mm depth decreased by 38 and $46 \%$, respectively, compared with the $0-100-\mathrm{mm}$ depth. The average macropore count at the first depth, however, is equal to that at depth four under ALF (Table 3).

Figure $2 \mathrm{c}$ shows that the trace for macropore count and soil depth is relatively steady for soil under ALF. In contrast, it fluctuates markedly within the $20-40-\mathrm{mm}$ soil depth under $\mathrm{KOP}_{40}$ and the maximum value is at the $110-130-\mathrm{mm}$ depth (Figure $2 \mathrm{c}$ ). The average macropore count under $\mathrm{KOP}_{22}$ is close to that under $\mathrm{KOP}_{40}$, with averages of 17 and 18 macropores, respectively, for the 360-mm soil depth. The values are similar for several depth ranges, which is depicted by the intersections of the two lines (Figure 2c). The maximum values of macropore counts under $\mathrm{KOP}_{40}$ are larger than those under $\mathrm{KOP}_{22}$ at depths 0-100, 100-200 and $200-300 \mathrm{~mm}$.

\section{Circularity}

Circularity is an important characteristic of pore shape. The average macropore circularity for the three treatments was in the order $\mathrm{ALF}>\mathrm{KOP}_{22}>\mathrm{KOP}_{40}$. The circularity of macropores under ALF (0.93) is larger than that under $\mathrm{KOP}_{22}(0.89)$ and $\mathrm{KOP}_{40}(0.90)$ at the first depth. The circularity of macropores under $\mathrm{KOP}_{22}(0.93)$ is approximately the same as that for ALF (0.93) at depth two (Table 3). Furthermore, the average macropore circularity increases with increasing soil depth (Tables 2 and 3). For soil under ALF, the variation in macropore circularity with soil depth is minimal (0.93-0.94). Macropore circularity increases by 6.1 and $4.1 \%$ (Table 3) from the first to the fourth depths in soil under $\mathrm{KOP}_{22}$ and $\mathrm{KOP}_{40}$. The larger circularity at the first depth under ALF could facilitate the infiltration of water into the deeper soil layers.

\section{Inner visualization and three-dimensional quantification}

The cross-section, profile and three-dimensional images of the macropores are plotted in Figures 3-5, respectively. Different types of macropore were observed for the three treatments. Figure 3 shows that macroporosity under $\mathrm{KOP}_{40}$ is greater than that under $\mathrm{KOP}_{22}$, which in turn is larger than that under ALF at the 20-mm soil depth. For the 120- and 220-mm depths, the macroporosity is greater under $\mathrm{KOP}_{40}$ than under $\mathrm{KOP}_{22}$, which has a macroporosity value similar to that under ALF. For profile images (where two images were used per plant), Figure 4 shows that the largest pore areas under $\mathrm{KOP}_{40}$ are larger than those under $\mathrm{KOP}_{22}$ and ALF, especially at the $0-300-\mathrm{mm}$ depth. In contrast to the large macropores for $\mathrm{KOP}_{40}$, most of the macropores under $\mathrm{KOP}_{22}$ resembled threadlike channels that reflect the growth route of fine roots. The macroporosity for the fourth depth is small for all treatments (Figures 3 and 4).

Macropore surface area, branch and junction densities and connectivity were derived from three-dimensional macropore 
Table 5 Macropore surface area density, branch density, connectivity and junction density derived from three-dimensional images of macropores in soil under purple alfalfa (ALF), 22-year-old Korshinsk peashrub $\left(\mathrm{KOP}_{22}\right)$ and 40-year-old Korshinsk peashrub $\left(\mathrm{KOP}_{40}\right)$ treatments in the northern Loess Plateau of China

\begin{tabular}{lcllc}
\hline & $\begin{array}{l}\text { Surface area } \\
\text { density / } \\
\mathrm{mm}^{2} \mathrm{~cm}^{-3}\end{array}$ & $\begin{array}{l}\text { Branch } \\
\text { density / } \\
\mathrm{N} \mathrm{cm}^{-3}\end{array}$ & $\begin{array}{l}\text { Junction } \\
\text { density / } \mathrm{N} \mathrm{cm}^{-3}\end{array}$ & Connectivity \\
\hline $\mathrm{ALF}$ & 4.81 & 0.04 & 0.01 & 45.28 \\
$\mathrm{KOP}_{22}$ & 11.27 & 0.07 & 0.03 & 151.31 \\
$\mathrm{KOP}_{40}$ & 30.43 & 0.18 & 0.08 & 339.49 \\
\hline
\end{tabular}

images (Table 5). Mean macropore surface area density under ALF treatment is the smallest $\left(4.81 \mathrm{~mm}^{2} \mathrm{~cm}^{-3}\right)$; it is $\sim 42 \%$ of $\mathrm{KOP}_{22}\left(11.27 \mathrm{~mm}^{2} \mathrm{~cm}^{-3}\right)$ and $\sim 16 \%$ of $\mathrm{KOP}_{40}\left(30.43 \mathrm{~mm}^{2} \mathrm{~cm}^{-3}\right)$ mean surface area densities (Table 5). Both branch and junction densities varied with treatment. Table 5 shows that soil under $\mathrm{KOP}_{40}$ has 2.6 and 4.4 times more branches and 3.4 and 8.3 times more junctions than soil under $\mathrm{KOP}_{22}$ and ALF treatments, respectively. Macropore continuity affects water flow and solute transport in soil, which also varied with treatment. The connectivity was validated by creating simple connected structures and measuring the related Euler characteristics. The connectivities in soil under $\mathrm{KOP}_{40}, \mathrm{KOP}_{22}$ and ALF are 339.49, 151.31 and 45.28, respectively. The large connectivity under $\mathrm{KOP}_{40}$ suggests more continuous pores in the soil system.

The three-dimensional visualization of macropores is shown in Figure 5. Macropore characteristics are different for the three different treatments. The two sample cores under $\mathrm{KOP}_{40}$ have more abundant and continuous macropores than those under the other two treatments (Figure 5). Macropores under $\mathrm{KOP}_{22}$ and $\mathrm{KOP}_{40}$ treatments are more evenly distributed along the soil profile in the core than those under ALF. Moreover, different forms of macropores were observed. Soil under ALF has the smallest connectivity, the most random distribution of pores and fewer continuous pores (Figure 5, Table 5). These are inter-aggregate macropores formed through repeated freezing and thawing or wetting and drying (Luo etal., 2010). Compared with continuous macropores, this form of macropore does not facilitate infiltration.

\section{Discussion}

\section{Macropore characteristics}

Macropores are preferential pathways for movement of water to depth in the soil following a rain event, which can reduce surface runoff (Li et al., 2009). With improved macropore characteristics, more rainwater can infiltrate the soil. Li \& Shao (2006) showed that soil physical properties can be improved by successions of natural vegetation from pioneer grassland to climax forest. The improvement can be attributed to enhanced root development, soil biological activity and root decay (De Gryze etal., 2006). Seobi et al. (2005) observed that total porosity of grass and agroforestry buffer zones at $0-76.2-\mathrm{mm}$ soil depth was three times greater than that of crop buffer zones. Udawatta et al. (2006) noted that average macropore counts under crops, grass and trees were 10, 14 and 36, respectively.

In this study, macroporosity under ALF (0.65\%) and KOP $(1.91 \%)$ was less than that under grass $(1.5 \%)$ and tree $(3.5 \%)$ buffer zones reported by Udawatta etal. (2006). The macropore counts under ALF (6) and KOP (17) were smaller than those reported for the grassland in inner Mongolia (Hu et al., 2015). In general, fewer macropores and less macroporosity decrease water transmission and increase surface runoff. Udawatta et al. (2006) observed that there were no significant differences in macropores at different (a)

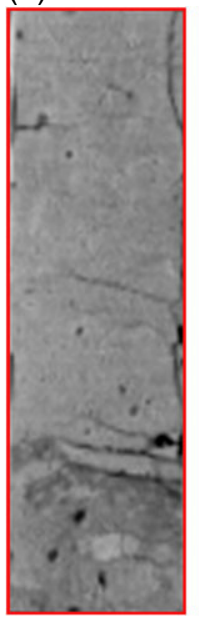

(b)

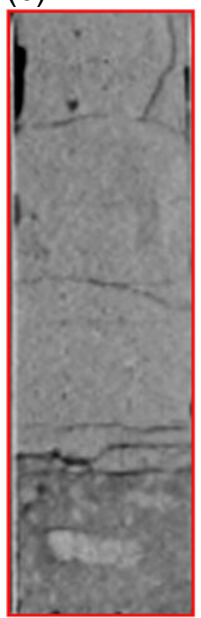

(c)

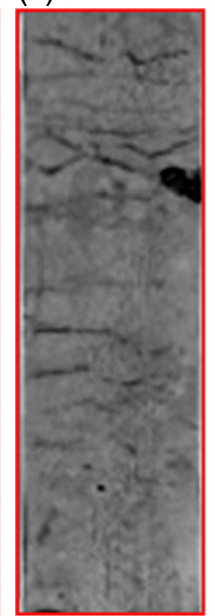

(d)

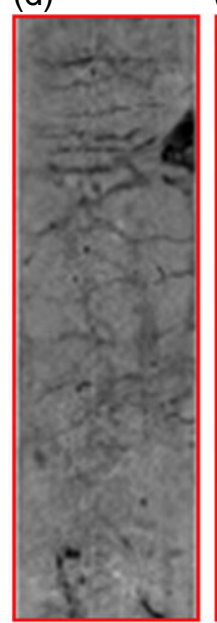

(e)

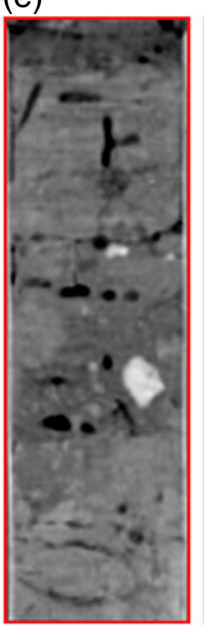

(f)

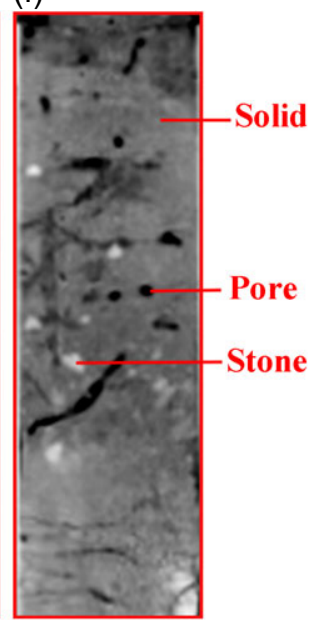

Figure 4 Longitudinal cross-sections of core samples taken under ALF (purple alfalfa; (a) and (b)), KOP 22 (22-year-old Korshinsk peashrub; (c) and (d)) and $\mathrm{KOP}_{40}$ (40-year-old Korshinsk peashrub; (e) and (f)) vegetation in the Loess Plateau. Macropores are shown in black, solid particles in grey and stones in white in the images. 
(a)

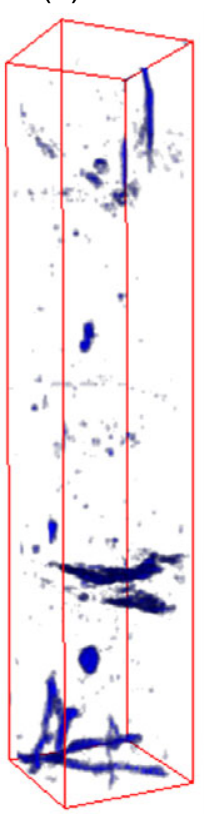

(b)

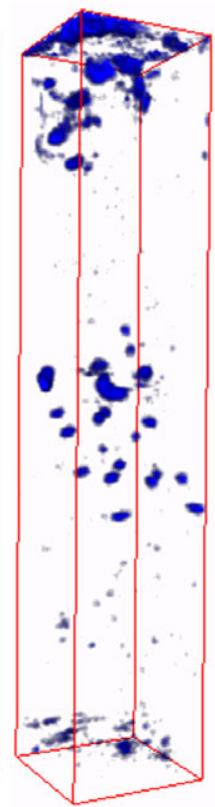

(c)

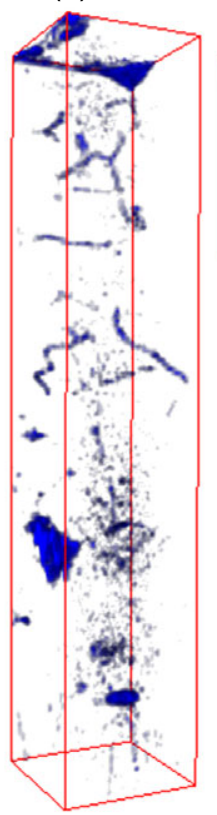

(d)

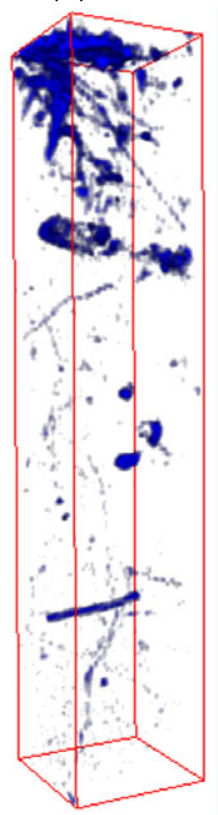

(e)

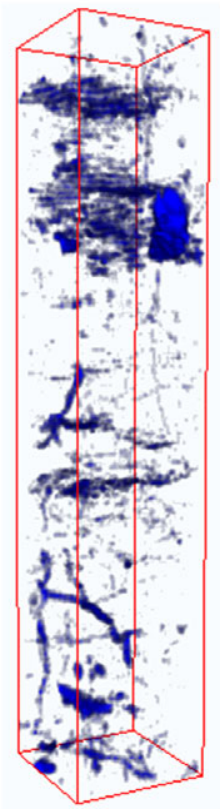

(f)

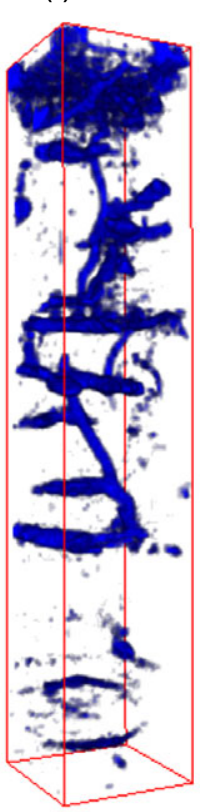

Figure 5 Three-dimensional images of the 0-360-mm depth soil cores under ALF (purple alfalfa; (a) and (b)), KOP 22 (22-year-old Korshinsk peashrub; (c) and (d)) and $\mathrm{KOP}_{40}$ (40-year-old Korshinsk peashrub; (e) and (f)) vegetation in the Loess Plateau. Macropores are shown in blue and solid particles in white in the three-dimensional images.

depths under agroforestry and grass buffer systems. Similarly here, macropore properties under ALF did not vary greatly with soil depth. However, there were large differences between the first and the fourth depths under $\mathrm{KOP}_{22}$ and $\mathrm{KOP}_{40}$ (Table 3). This suggested that the soil under the KOP treatments had a better macropore structure than that under ALF. The older vegetation was associated with macropore enlargement because of the stronger and larger roots, as in $\mathrm{KOP}_{40}$.

More irregular pores result in more resistance to flow because of the greater pore-wall surface area. Luo et al. (2010) noted that macropores formed by roots were continuous and round. In this study, KOP increased irregular macropores in the soil more than for ALF. Rachman et al. (2005) observed $10 \%$ less circularity in soil under grass than in soil under crops in Iowa, USA. The larger is the pore, the smaller is the probability that it will be round (Lebron et al., 2002). Our results support the observation that the pore circularity of soil under woody plants (KOP) is less than that under herbaceous plants (ALF). Macropores at greater soil depths tend to be more circular than those at shallower depths (Rachman et al., 2005). In this study, soil depth did not have an adverse effect on macropore circularity under ALF treatment, but it increased slightly with depth under the KOP treatments (Table 3). Kim et al. (2010) noted that circularity under arable land was less (0.77-0.80) than that under ALF (0.89) and KOP (0.95). Pore shape, roughness and circularity could change with aggregation, root activity and macrofauna activity (Rachman et al., 2005).

The conductivity of macropores in terms of water flow depends strongly on their three-dimensional geometry and topology.
Quantification of the three-dimensional macropore network has improved our understanding of soil structure under different vegetation covers. Surface area $\left(230 \mathrm{~mm}^{2} \mathrm{~cm}^{-3}\right)$ and branch $\left(279 \mathrm{~cm}^{-3}\right)$ and junction densities $\left(117 \mathrm{~cm}^{-3}\right)$ observed by Munkholm et al. (2012) in an undisturbed field soil were far larger than those for $\mathrm{KOP}_{40}$ in this study $\left(30.43 \mathrm{~mm}^{2} \mathrm{~cm}^{-3}, 0.18 \mathrm{~cm}^{-3}\right.$ and $0.08 \mathrm{~cm}^{-3}$, respectively). Differences between these results and ours could arise partly from the differences in soil porosity and CT scanner resolution.

\section{Soil properties}

Soil organic matter contents reported by Udawatta et al. (2006), Kim etal. (2010) and $\mathrm{Hu}$ etal. (2015) were larger than those observed in our study $\left(1.9-13.9 \mathrm{~g} \mathrm{~kg}^{-1}\right)$. Organic matter content decreased with increasing soil depth (Table 1). Positive correlations have been shown between organic matter content and soil pore properties by others (Luo etal., 2010; Zhao etal., 2010; Ruan etal., 2015). The larger organic matter content at the first soil depth corresponded to larger macropore counts under $\mathrm{KOP}_{22}$ and $\mathrm{KOP}_{40}$ in our study (Table 3). Unlike the organic matter content, however, macropore properties do not decrease consistently with increasing soil depth. This could be because of the much smaller organic matter contents in our samples (2.6-10.1 $\mathrm{g} \mathrm{kg}^{-1}$ ) (Table 1) than those reported by Luo et al. (2010) $\left(5-75 \mathrm{~g} \mathrm{~kg}^{-1}\right)$, Zhao et al. (2010) (17-73 $\left.\mathrm{g} \mathrm{kg}^{-1}\right)$ and Ruan etal. (2015) $\left(2-82 \mathrm{~g} \mathrm{~kg}^{-1}\right)$. This suggested that macropore structure was not affected primarily by organic matter content in the Liudaogou Catchment (Table 1). 


\section{Root properties}

The plant root system is critical for the development of soil macropores by root decay and penetration to depth in the soil. Table 4 shows that root properties for the four soil depths under KOP treatments varied greatly. The root volume ratio varied from $0.01 \%$ at the second depth under $\mathrm{KOP}_{22}$ to $0.14 \%$ at the first depth under $\mathrm{KOP}_{40}$. The observed range in this study was smaller than that $(0.03-0.28 \%)$ reported by Ji et al. (2012) in a study on Black locust (Robinia pseudoacacia L.) and Oriental arborvitae (Platycladus orientalis L.) root systems in Ji County in the Loess Plateau. The correlation between roots and macropore properties could be affected by inter-aggregation of macropores and other bio-pores such as ant tunnels (Tschinkel, 2003), but this was not so in our study. Root characteristics were not consistent with the distribution of macropores and did not agree with observations from the images (Figures 4 and 5).

The root biomass for different regions of the Loess Plateau had a vertical distribution similar to that we observed for ALF. In general, the root biomass of ALF decreased with increasing soil depth (Walley etal., 1996; Wan etal., 2004; Wu etal., 2007). However, the distribution of macroporosity and macropore counts under ALF in this study did not decrease with increasing soil depth (Table 3 ). The contrast between macropore and root property distributions could result from differences in the scanned macropore structure and real root structure. Determination of the correlations between root indices and macropore properties could foster better understanding of pore structure in relation to vegetation growth in the Loess Plateau.

\section{Conclusions}

The restoration of Korshinsk peashrub improved soil macroporosity, macropore counts, largest pore area, surface area density, macropore branch density, junction density and connectivity more than for ALF. The longer the restoration time of KOP, the better were the macropore properties. Macropore counts, however, were approximately the same for $\mathrm{KOP}_{22}$ and $\mathrm{KOP}_{40}$. Compared with $\mathrm{KOP}_{22}$, $\mathrm{KOP}_{40}$ affected soil macroporosity and the largest pore area positively at the 110-255-mm depth. The results of this study should improve our understanding of soil macropore structure at depth in the northern Loess Plateau. This knowledge could in turn be used to devise strategies for sustainable recovery of vegetation and reduce soil erosion in this region.

\section{Acknowledgements}

This research was supported by the National Natural Science Foundation of China (41390463, 41530854 and 41571221). The authors wish to acknowledge the technical advice regarding CT scans from Zhijian Dong and Fang Gao. The authors also thank the anonymous reviewers and editors for their valuable suggestions and critical and positive comments on earlier versions of the manuscript.

\section{References}

Alaoui, A., Lipiec, J. \& Gerke, H.H. 2011. A review of the changes in the soil pore system due to soil deformation: a hydrodynamic perspective. Soil \& Tillage Research, 115-116, 1-15.

Cao, S.X., Chen, L. \& Yu, X.X. 2009. Impact of China's Grain for Green project on the landscape of vulnerable arid and semi-arid agricultural regions: a case study in northern Shaanxi Province. Journal of Applied Ecology, 46, 536-543.

Chen, H.S., Shao, M.A. \& Li, Y.Y. 2008. Soil desiccation in the Loess Plateau of China. Geoderma, 143, 91-100.

Cnudde, V. \& Boone, M.N. 2013. High-resolution X-ray computed tomography in geosciences: a review of the current technology and applications. Earth-Science Reviews, 123, 1-17.

De Gryze, S., Jassogne, L., Six, J., Bossuyt, H., Wevers, M. \& Merckx, R. 2006. Pore structure changes during decomposition of fresh residue: X-ray tomography analyses. Geoderma, 134, 82-96.

Doube, M., Klosowski, M.M., Arganda-Carreras, I., Cordelieres, F.P., Dougherty, R.P., Jackson, J.S. et al. 2010. BoneJ: free and extensible bone image analysis in ImageJ. Bone, 47, 1076-1079.

Elliot, T.R., Reynolds, W.D. \& Heck, R.J. 2010. Use of existing pore models and X-ray computed tomography to predict saturated soil hydraulic conductivity. Geoderma, 156, 133-142.

FAO 1989. Carte mondiale des sols. Légende révisée. Rapport sur les ressources en sols du monde N 60. FAO, Rome, p125.

He, X.B., Li, Z.B., Hao, M.D., Tang, K.L. \& Zheng, F.L. 2003. Down-scale analysis for water scarcity in response to soil-water conservation on Loess Plateau of China. Agriculture, Ecosystems \& Environment, 94, 355-361.

Hu, W., Shao, M.A., Wang, Q.J., Fan, J. \& Horton, R. 2009. Temporal changes of soil hydraulic properties under different land uses. Geoderma, 149, 355-366.

Hu, X., Li, Z.C., Li, X.Y. \& Liu, Y. 2015. Influence of shrub encroachment on CT-measured soil macropore characteristics in the Inner Mongolia grassland of northern China. Soil \& Tillage Research, 150, 1-9.

Jarvis, N.J. 2007. A review of non-equilibrium water flow and solute transport in soil macropores: principles, controlling factors and consequences for water quality. European Journal of Soil Science, 58, 523-546.

Ji, J., Kokutse, N., Genet, M., Fourcaud, T. \& Zhang, Z. 2012. Effect of spatial variation of tree root characteristics on slope stability. A case study on Black Locust (Robinia pseudoacacia) and Arborvitae (Platycladus orientalis) stands on the Loess Plateau, China. Catena, 92, 139-154.

Jia, Y.H. \& Shao, M.A. 2014. Dynamics of deep soil moisture in response to vegetational restoration on the Loess Plateau of China. Journal of Hydrology, 519, 523-531.

Jiao, F., Wen, Z.M. \& An, S.S. 2011. Changes in soil properties across a chronosequence of vegetation restoration on the Loess Plateau of China. Catena, 86, 110-116.

Kim, H., Anderson, S.H., Motavalli, P.P. \& Gantzer, C.J. 2010. Compaction effects on soil macropore geometry and related parameters for an arable field. Geoderma, 160, 244-251.

Lebron, I., Suarez, D.L. \& Schaap, M.G. 2002. Soil pore size and geometry as a result of aggregate size distribution and chemical composition. Soil Science, 167, 165-172.

Li, Y.Y. \& Shao, M.A. 2006. Change of soil physical properties under long-term natural vegetation restoration in the Loess Plateau of China. Journal of Arid Environments, 64, 77-96.

Li, X.Y., Yang, Z.P., Li, Y.T. \& Lin, H. 2009. Connecting ecohydrology and hydropedology in desert shrubs: stemflow as a source of preferential flow in soils. Hydrology \& Earth System Sciences, 13, 1133-1144. 
Li, W.Z., Zhou, H., Chen, X.M., Peng, X.H. \& Yu, X.C. 2014. Characterization of aggregate microstructures of paddy soils under different patterns of fertilization with synchrotron radiation micro-CT. Acta Pedologica Sinica, 51, 67-74.

Luo, L.F., Lin, H. \& Li, S.C. 2010. Quantification of 3-D soil macropore networks in different soil types and land uses using computed tomography. Journal of Hydrology, 393, 53-64.

Munkholm, L.J., Heck, R.J. \& Deen, B. 2012. Soil pore characteristics assessed from X-ray micro-CT derived images and correlations to soil friability. Geoderma, 181-182, 22-29.

Rab, M.A., Haling, R.E., Aarons, S.R., Hannah, M., Young, I.M. \& Gibson, D. 2014. Evaluation of X-ray computed tomography for quantifying macroporosity of loamy pasture soils. Geoderma, 213, 460-470.

Rachman, A., Anderson, S.H. \& Gantzer, C.J. 2005. Computedtomographic measurement of soil macroporosity parameters as affected by stiff-stemmed grass hedges. Soil Science Society of America Journal, 69, 1609-1616.

Rasband, W. 2002. NIH ImageJ. Research Service Branch, National Institute of Mental Health, National Institute of Health, Bethesda, MD [WWW document]. URL http://rsb.info.nih.gov/ij/docs/intro.html [accessed on 10 December 2014].

Ruan, X.Z., Cheng, J.H., Zhang, H.J., Du, S.C., Li, S.Y., Zhang, F.M. et al. 2015. Soil macropore characteristics of different wood land and their influencing factors on Simiansan mountain in Chongqing. Journal of Soil \& Water Conservation, 29, 68-74.

Scott, H.D. 2000. Soil Physics: Agricultural and Environmental Applications. Iowa State University Press, Ames, IO.

Seobi, T., Anderson, S.H., Udawatta, R.P. \& Gantzer, C.J. 2005. Influence of grass and agroforestry buffer strips on soil hydraulic properties for an albaqualf. Soil Science Society of America Journal, 69, 893-901.

Tschinkel, W.R. 2003. Subterranean ant nests: trace fossils past and future? Palaeogeography, Palaeoclimatology, Palaeoecology, 192, 321-333.

Udawatta, R.P., Anderson, S.H., Gantzer, C.J. \& Garrett, H.E. 2006. Agroforestry and grass buffer influence on macropore characteristics. Soil Science Society of America Journal, 70, 1763-1773.
Walley, F.I., Tomm, G.O., Matus, A., Slinkard, A.E. \& Kessel, C.V. 1996. Allocation and cycling of nitrogen in an alfalfa-bromegrass sward. Agronomy Journal, 88, 834-843.

Wan, S.M., Hu, S.L., Huang, Q.H., Wang, L.C., Zhao, S.Z. \& Hu, J.H. 2004. Study on root system development ability of alfalfa cultivars. Acta Botanica Boreali-Occidentalia Sinica, 24, 2048-2052.

Wang, Y.Q., Shao, M.A. \& Shao, H.B. 2010. A preliminary investigation of the dynamic characteristics of dried soil layers on the Loess Plateau of China. Journal of Hydrology, 381, 9-17.

Wei, X.R., Huang, M.B., Shao, M.A., Li, L., Zhang, X. \& Horton, R. 2013. Shrubs increase soil resources heterogeneity along semiarid grass slopes in the Loess Plateau. Journal of Arid Environments, 88, $175-183$.

Wu, X.W., Han, Q.F. \& Jia, Z.K. 2007. Study on root system development ability and comparison of root and crown traits among alfalfa cultivar. Acta Agriculturae Boreali-occidentalis Sinica, 16, 80-86.

Xu, M., Zhang, J., Liu, G.B. \& Yamanaka, N. 2014. Soil properties in natural grassland, Caragana korshinskii planted shrubland, and Robinia pseudoacacia planted forest in gullies on the hilly Loess Plateau, China. Catena, 119, 116-124.

Yang, Y.H., Wu, J.C., Mao, Y.P., Han, Q.Y. \& He, F. 2013. Using computed tomography scanning to study soil pores under different soil structure improvement measures. Transactions of the Chinese Society of Agricultural Engineering, 29, 99-108.

Zhao, S.W., Zhao, Y.G. \& Wu, J.S. 2010. Quantitative analysis of soil pores under natural vegetation successions on the Loess Plateau. Science China Earth Sciences, 53, 617-625.

Zhou, H.J., Rompaey, A.V. \& Wang, J.A. 2009. Detecting the impact of the "Grain for Green" program on the mean annual vegetation cover in the Shaanxi province, China using SPOT-VGT NDVI data. Land Use Policy, 26, 954-960.

Zhou, D.C., Zhao, S.Q. \& Zhu, C. 2012. The Grain for Green Project induced land cover change in the Loess Plateau: a case study with Ansai County, Shanxi Province, China. Ecological Indicators, 23, 88-94. 